
Dr Čedomir Gacović, pukovnik, dipl. inž. Vojna akademija,
Beograd

\section{ISPITIVANJE UTICAJA OBLAKA SMETNJI NA MONOIMPULSNI NIŠANSKI RADAR I PROTIVRADARSKE RAKETE*}

UDC: $623.46:: 621.396 .96: 621.391 .82$

Rezime:

U ovom radu razmatrane su metodologije i eksperimentalni rezultati ispitivanja uticaja oblaka smetnji na monoimpulsne nišanske radare i protivradarske rakete. Rezultati su pokazali ispravnost postavljenih teorijskih modela $i$ izvršenih analiza primene oblaka smetnji tokom agresije na Jugoslaviju 1999. godine.

Ključne reči: nišanski radar, monoimpulsni radar, uglovna greška, oblak smetnji, ometanje, raketni sistemi, protivavionska raketa.

\title{
ANALYSIS OF THE INFLUENCE OF JAMMING CLOUDS ON MONOPULSE TRACKING RADARS AND ANTIRADAR MISSILES
}

Summary:

This paper considers the methods and the experimental results of the analysis of the jamming cloud influence on monopulse tracking radars and antiradar missiles. The results confirmed the value of the set theoretical models and the analyses of the application of jamming clouds carried out during the NATO aggression on Yugoslavia in 1999.

Key words: tracking radar, monopulse radar, angle error, jamming cloud, jamming, missile systems, antiaircraft missile.

\section{Uvod}

Zaštita radarskih sistema od protivradarskih raketa primenom oblaka smetnji, koja je primenjena u toku agresije na Jugoslaviju 1999. godine, bila je na osnovu mnogih pokazatelja uspešna. Brojne metode zaštite bile su primenjene, uglavnom, samo na osnovu teorijskih analiza. Bilo je očigledno da je i protivnik koristio oblake smetnji za zaštitu od protivavionskih (PA) raketa, i za pomeranje nišanskih linija, odnosno ekvisig-

Rad je prezentiran na naučno-stručnom skupu TOC KoV „Ispitivanje kvaliteta sredstava NVO“, 02. 12. 2003. u Beogradu. nalnih (ESP) pravaca nišanskih radara sa cilja. Lažno aktiviranje bojnih glava i promašaji naših PA raketa idu u prilog toj pretpostavci.

Zbog toga je doneta odluka da se u širem rejonu Niša, na vežbovnoj prostoriji 230. raketnog puka PVO, izvrši ispitivanje uticaja oblaka smetnji na RS PVO, KUBM/M3. To je izuzetno složen sistem, sa komponentama koje se, sistemski gledano, nalaze u osnovi i najsavremenijih raketnih sistema iste namene. Osim toga, princip vođenja PA rakete ovog sistema na cilj gotovo je identičan principu vođenja protivradarskih raketa na radar. 
Upravo radi toga je izučavanje uticaja oblaka smetnji na ovaj sistem i mogućnost primene sistema u tim uslovima od velikog značaja i iz edukativnih razloga.

Ciljevi ispitivanja bili su, osim verifikacija dela teorijskih rezultata, nalaženje mogućnosti za primenu oblaka smetnji u obuci operatora radarskih stanica za rad u uslovima protivelektronske borbe (PED). Ispitivanja su vršena u okviru RS PVO KUB-M/M3 i zbog toga što je $u$ tom sistemu primenjen savremeni monoimpulsni koncept u nišanskom radaru 1S31 i u radarskoj glavi za samonavođenje rakete $3 \mathrm{M} 9$.

Osnovna, početna ideja eksperimenta bila je formiranje parnog modela oblaka smetnji i ispitivanje uticaja takvog oblaka na nišanski radar i RGS rakete $u$ različitim uslovima. Cilj je bio da se dobiju odgovori na tri osnovna pitanja, koja se odnose na: uticaj oblaka smetnji na nišanski radar 1S31 RS PVO KUB-M/M3, mogućnost primene oblaka smetnji za zaštitu od protivradarskih raketa i uticaj oblaka smetnji na rakete 3M9 RS PVO KUB-M/M3.

\section{Ispitivanje uticaja oblaka smetnji na nišanski radar}

Planirano je da se eksperimenti vrše tako što bi helikopter izbacivao paketiće pasivnih dipola, formirao oblake pasivnih smetnji, koje bi zatim osvetljavao ometačkim signalima na frekvenciji nišanskog radara 1S31. Nišanski radar zahvatao bi helikopter - cilj, a pomoću televizijsko-optičkog sistema 9Š33 merilo bi se odstupanje optičke ose, odnosno ESP od cilja. Merenja bi se vršila u vari- janti primene pasivnog oblaka smetnji, $\mathrm{tj}$. bez osvetljavanja, i u varijanti primene kompletnog oblaka smetnji pri osvetljavanju signalima sa helikoptera.

Zbog troškova i složenosti organizacije navedenih eksperimenata i zbog nemogućnosti obezbeđenja predajnika osvetljenja ometačkim signalima na frekvenciji nišanskog radara, odustalo se od navedene pune varijante ispitivanja. Umesto toga eksperimenti su se vršili tako što su dve radarske stanice za osmatranje i navođenje RStON-1 RStON-2, razmeštene nedaleko jedna od druge, zbog potrebe da se izvrši sinhronizacija repeticionih frekvencija nišanskih radara (slika 1).

Nišanski radar ometač $\left(\mathrm{NR}_{\mathrm{OM}}\right)$, iz RStON-1 (radarska stanica za osmatranje i navođenje), proglašen je za ometač, a nišanski radar NR, iz RStON-2, za ispitivani nišanski radar. Radne frekvencije nišanskih radara u radarskim stanicama puka razlikuju se zbog isključenja međusobnog ometanja nesinhronim impulsnim smetnjama, ali i zbog mogućeg oštećenja

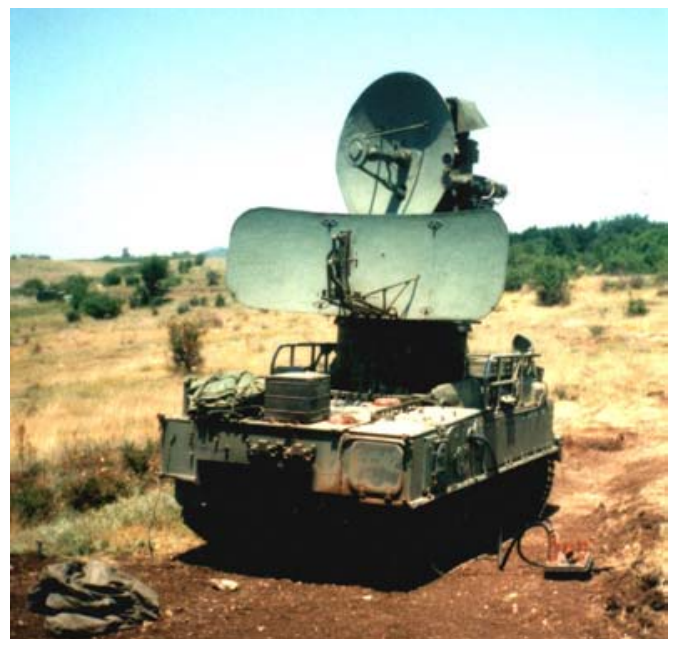

Sl. 1 - Radarska stanica za osmatranje i navodenje 
prijemnika jednog radara predajnim signalima drugog. Za potrebe eksperimenta izvršeno je kompletno prepodešavanje $\mathrm{NR}_{\mathrm{OM}}$, kako bi mogao preuzeti funkciju ometača radara NR. Zbog toga su radarske stanice postavljene tako da nije bilo optičke vidljivosti između njih. Postavljene su duž druge izohipse kote 369 iznad sela Čamurlije (sekcija 582 Niš 1:100 000), čime su obezbeđene iste nadmorske visine stanica (slika 4).

Na koti 322 iste sekcije, iznad sela Balajnac, formirane su dve grupe uglovnih reflektora na istoj visini. Grupe su, zavisno od eksperimenta, imale ulogu pasivnih, aktivnih ili kompletnih oblaka smetnji. Formirane su od dve vrste uglovnih reflektora u različitim kombinacijama, kao što je prikazano na slikama 2 i 3 . Oni veći su formacijski reflektori dodeljeni svakom puku. Manji uglovni reflektori, sa dimenzijama jedne stranice između 8 i $15 \mathrm{~cm}$, konstruisani su specijalno za ove eksperimente. Prethodna ideja da se stalni odrazi pojačavaju posipanjem dipol-reflektorima, koja je korišćena $\mathrm{u}$ toku rata, nije se pokazala uspešnom u ovim eksperimentima. Zbog malih dimenzija $(\lambda / 4)$ reflektori su se gubili u travi, i nije se primećivao njihov uticaj na radarski signal. Naravno, to ne mora biti konačan odgovor na pitanje o efikasnosti dipol-reflektora. Verovatno bi se sasvim drugačiji efekti dobili u slučaju povećanja upadnih uglova radarskih signala, što bi bilo interesantno sa stanovišta zaštite od protivradarskih raketa. Karakteristike upotrebljenih uglovnih reflektora nisu snimane. Postavljeni su na osnovu teorijskih pretpostavki oblika njihovih sekundarnih dijagrama zračenja. Kompletna ispitivanja ,malih" uglovnih reflektora vrše se u VA Vojske SCG.

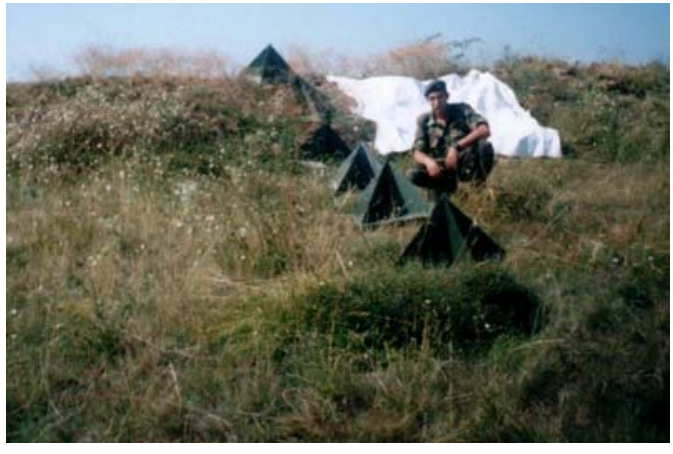

Sl. 2 - Grupa od 6 ,, velikih“ linijski postavljenih uglovnih reflektora

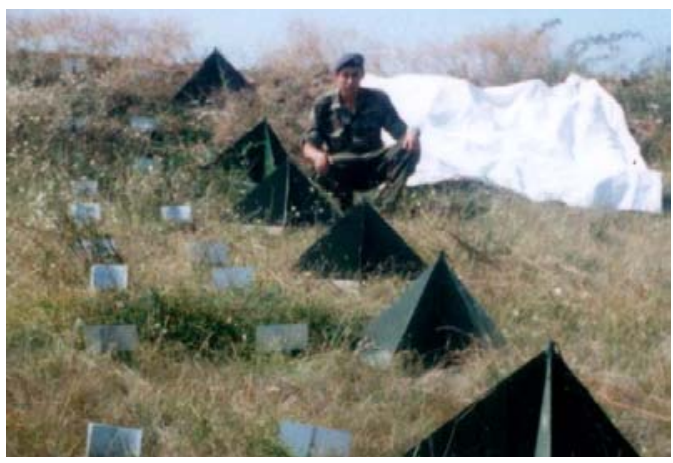

Sl. 3 - Grupa od 6 ,, velikih" i 12 ,malih" uglovnih reflektora

Grupe uglovnih reflektora obeležene su belom tkaninom kako bi se mogle uočiti pomoću televizijsko-optičkog vizira (TOV) $12 \mathrm{~km}$ udaljenih radarskih stanica (slika 4).

Merenje uglovne greške, odnosno odstupanje ESP nišanskog radara od izabranog cilja, vršilo se na sledeći način: najpre bi se jedna od dve grupe uglovnih reflektora proglasila za cilj, čime bi ona druga automatski bila ometačka. Nišanski radar NR bi se pomoću TOV-a (televizijsko-optički vizir) naveo na čaršav grupe reflektora koja je proglašena ciljem i izvršio zahvat. Zatim bi se merio položaj ESP pomoću precizne uglovne skale. Položaj pseudocentra odraza merio 
bi se tek nakon 8 do 10 sekundi stabilnog zahvata. Ovo vreme proisteklo je iz uslova da vreme stabilnog zahvata bude veće ili jednako vremenu inercionog praćenja koje iznosi 3 do $4 \mathrm{~s}$. Funkcije gustine verovatnoće snimale su se na osnovu 20 izvršenih zahvata iste grupe reflektora, $\mathrm{u}$ istim uslovima, osim $u$ trećem eksperimentu, gde je zbog nestabilnog zahvata broj merenja povećan na 40 .

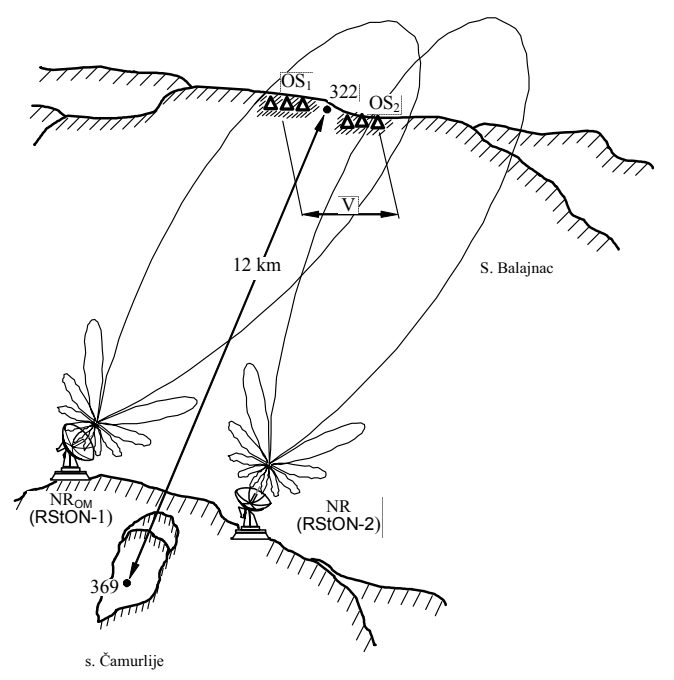

Sl. 4 - Raspored radarskih stanica i oblaka smetnji u širem rejonu Niša

Odlučujući faktor da se broj merenja ograniči na 20 bio je smanjenje vremena opitovanja, odnosno rada radarskih stanica. To ne predstavlja malu veličinu, budući da je u toku ispitivanja izvršeno 1020 merenja, ne računajući ona koja su vršena radi ustanovljavanja najbolje kombinacije grupa.

U drugom slučaju bi se druga grupa reflektora proglasila za cilj, odnosno vršio bi se zahvat te grupe reflektora i merio uticaj prve grupe koja se proglašava ometačkom tačkom.
U trećem slučaju bio bi zahvaćen geometrijski centar i merio položaj pseudocentra.

Grupe uglovnih reflektora imale su ulogu parnog pasivnog oblaka smetnji, ako je bio uključen samo nišanski radar, odnosno kompletnog oblaka smetnji ako ih je, pored NR, osvetljavao predajnik $\mathrm{NR}_{\mathrm{OM}}$. Merenja su vršena u tri varijante, $\mathrm{i}$ to kada su grupe uglovnih reflektora iste ili približno iste, kada je prva grupa veća od druge, kada je druga grupa veća od prve, i kombinacijom grupa. Pri tome je međusobni razmak grupa reflektora - baza uziman kao parametar. Biran, je takođe, za tri specifična slučaja na osnovu teorije o rezolucionim uglovima kanala za automatsko praćenje ciljeva po uglovnim koordinatama [2]:

- razmak pri kojem je međusobni ugao grupa reflektora $\Theta$ posmatran sa mesta NR bio manji od rezolucionog ugla nišanskog radara $\Theta_{r}$, tj. $\Theta<\Theta_{r}$;

- razmak pri kojem je $\Theta \approx \Theta_{\text {r }}$;

- razmak pri kojem je $\Theta>\Theta_{\text {r. }}$.

U svim merenjima servosistem za pomeranje antene nišanskog radara po mesnom uglu isključivan je nakon postavljanja na visinu oblaka smetnji.

Rezultati ispitivanja pokazali su da je ovako definisani eksperiment potpuno uspeo.

Pretpostavke o mogućnosti formiranja oblaka smetnji na zemlji bile su ispravne. Jedina, mada veoma važna nepogodnost, bila je nemogućnost provere rada radara u faznom režimu, zbog nemogućnosti stvaranja pokretnih oblaka smetnji, kako je to u punoj konfiguraciji eksperimenta zamišljeno. Ipak, postavka je dobra podloga za nastavak istraživanja u ovom području. 
Otklonjene su mnoge dileme koje je ekipa imala na početku eksperimenta. Eksperimenti sa imitiranjem treptećih smetnji nisu uspeli, zbog nemogućnosti pomeranja dijagrama zračenja $\mathrm{NR}_{\mathrm{OM}}$ po azimutu, brzinom kojom bi se mogle imitirati bar spore trepteće smetnje. Naime, širina propusnog opsega servosistema nišanskog radara koji ,glumi“" ometač je reda nekoliko $\mathrm{Hz}$, a ručno pomeranje snopa u tom ritmu je skoro nemoguće zbog relativno velike širine dijagrama zračenja na $12 \mathrm{~km}$ od radara, tj. na mestu oblaka smetnji. Mogućnost sofisticiranog upravljanja servosistemom ostaje da se proveri u nastavku istraživanja.

\section{Ispitivanje mogućnosti primene oblaka smetnji za zaštitu od protivradarskih raketa - metodika 2}

U konfiguraciji prikazanoj na slici 4 $\mathrm{NR}_{\mathrm{OM}}$ bio bi postavljen na mesto $\mathrm{OS}_{1}$, a NR bi ostao na istom mestu. Antena $\mathrm{NR}_{\mathrm{OM}}$ bi se usmerila na NR i uključio predajnik. U nišanskom radaru NR uključio bi se režim praćenja izvora šumnih smetnji, zbog povećanog dinamičkog opsega u tom režimu i izvršio zahvat. Nakon toga bi se na opisani način proverio položaj ESP antene NR. Budući da NR ima ulogu protivradarske rakete, njegov predajnik mora biti isključen.

Varijanta nije proverena zbog opasnosti od oštećenja prijemnika NR predajnim signalima $\mathrm{NR}_{\mathrm{OM}}$ velike snage. Umesto toga, ekipa se odlučila za eksperiment u kojem bi oblaci smetnji $\mathrm{OS}_{1} \mathrm{i}$ $\mathrm{OS}_{2}$ imali posredne uloge. Raspored radarskih stanica i oblaka smetnji ostao bi isti kao na slici 4 , s tom razlikom što bi $\mathrm{NR}_{\mathrm{OM}}$ radio samo na predaji, a NR samo na prijemu. Oblak smetnji $\mathrm{OS}_{1}$ proglašen je za radar - cilj, a $\mathrm{OS}_{2}$ ima svoju stvarnu ulogu - odvlačenje ESP antene NR (protivradarske rakete) od $\mathrm{OS}_{1} \mathrm{tj}$. radara - cilja. Imitiranje većeg signala $\mathrm{OS}_{1} \mathrm{u}$ odnosu na signal $\mathrm{OS}_{2}$ vršen je pravilnim usmeravanjem dijagrama zračenja $\mathrm{NR}_{\mathrm{OM}}$.

\section{Ispitivanje uticaja oblaka smetnji na radarsku glavu PA rakete - metodika 3}

Kao i u prethodnom slučaju, predviđeno je da se eksperiment vrši tako što bi helikopter formirao oblake pasivnih dipola koje bi osvetljavao signalima na frekvenciji predajnika osvetljenja kanala vođenja rakete na cilj. Ovako definisani eksperimenti nisu se mogli izvršiti iz već opisanih razloga, koji su ovde pojačani potrebom da signali osvetljenja sa helikoptera imaju i komponentu Doplerovog pomaka [3]. Varijanta primene oblaka smetnji na zemlji ne može se ostvariti i zbog nemogućnosti uvođenja brzine $u$ signal osvetljenja. Predajnik osvetljenja cilja RstON-a osvetljava cilj veoma stabilnim signalima na fiksnoj frekvenciji $f_{0}$, koja se može menjati samo pre lansiranja rakete.

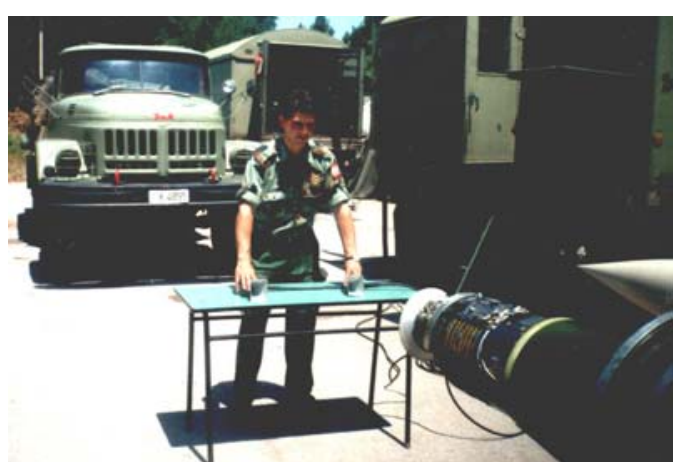

Sl. 5 - Postavljanje levak-antena imitatora cilja $i$ ometača ispred antene rakete 3 M9M3 - pogled sa leve strane 
Zbog toga je odlučeno da se eksperimenti izvedu na sledeći način:

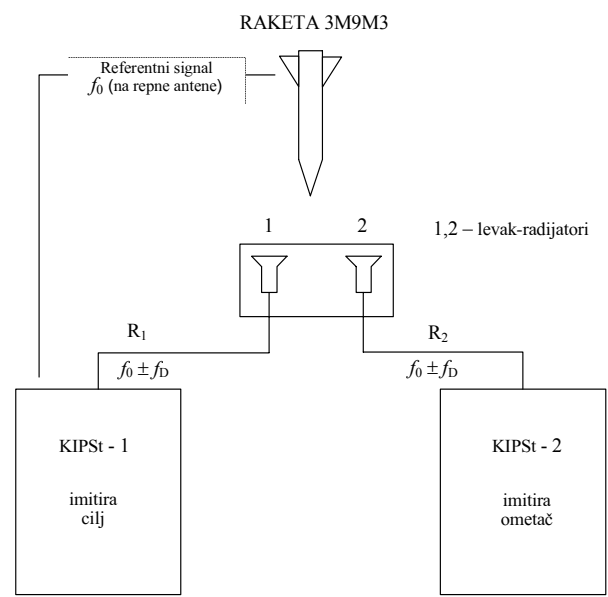

Sl. 6 - Povezivanje kontrolno-ispitnih pokretnih stanica sa raketom $3 M 9 M 3$

Raketni sistem PVO KUB-M/M3 opremljen je kontrolno-ispitnim pokretnim stanicama (KIPSt) u okviru kojih se nalazi komplet instrumenata za proveru RGS raketa. Za ovaj eksperiment stanice su smeštene jedna pored druge (slika 5) i povezane raketom po šemi prikazanoj na slici 6. Stanica KIPSt-1 imitira cilj, tako da osim glavnog čeonog kanala na frekvenciji $f_{0} \pm f_{\mathrm{D}}$ (levak-antena 1 ) obezbeduje i referentni signal $f_{0}$ preko repne antene rakete [4].

Planirano je da se eksperiment izvede tako što bi se u prvoj varijanti menjali odnosi snaga $R_{1}$ i $R_{2}, \mathrm{tj} . Z_{0}$ sa bazom (B) kao parametrom. Zatim bi se uz konstan$\tan$ odnos $Z_{0}$ menjala baza u skladu sa rezolucionim uglom $\left(\Theta_{\mathrm{r}}\right)$ RGS rakete.

Rezultati ispitivanja PA rakete novije generacije bili su bitno drugačiji od onih koje je ekipa očekivala. Pokazalo se da su ugrađene zaštite od ometanja po uglu znatno efikasnije nego što se pretpostavljalo na osnovu prethodnih teorijskih razmatranja. Budući da proizvođač rakete nije dao sve podatke o raketi, uključujući električne šeme pojedinih vitalnih sklopova, zaključeno je da bi eksperimente trebalo nastaviti nakon detaljnijeg proučavanja konstrukcije rakete, uz angažovanje stručnjaka iz VTI i TOC-a. Zbog toga je nakon većeg broja izvršenih merenja $(>50)$, konstatovano da je ova raketa izuzetno otporna na ometanje po uglovnom kanalu. Raketa se drži zahvaćenog cilja nezavisno od odnosa snaga $Z_{0}$ i baze B. Do prezahvata ometača dolazi tek ako se antena ometača poklopi sa antenom cilja, i tu ostaje izvesno vreme. U suprotnom, ako se antena ometača samo prevuče preko antene cilja, raketa nastavlja da prati cilj. Ako se tome doda već navedena karakteristika ove rakete da je u stanju da za svega $0,3 \mathrm{~s}$ ponovo zahvati cilj po brzini, ako se desi da ga, na primer, zbog ometanja izgubi - može se zaključiti da je raketa izuzetno otporna na protivelektronska dejstva. Unutar vremena inercionog praćenja po uglu od 3 do $4 \mathrm{~s}$, raketa može $10(3 / 0,3)$ puta da izgubi i ponovo zahvati cilj po brzini, što nije bio slučaj sa starijom raketom 3M9M, kojoj je za ponovni zahvat cilja bilo potrebno vreme od 2 do $3 \mathrm{~s}$.

\section{Deo eksperimentalnih rezultata ispitivanja uticaja oblaka smetnji}

U eksperimentu 1 koji je vršen po metodici ispitivanja 1 pri $\Theta<\Theta_{\mathrm{r}}$, oblaci smetnji $\mathrm{OS}_{1}$ i $\mathrm{OS}_{2}$ su pasivni. Uglovno rastojanje oblaka smetnji $\mathrm{OS}_{1}$ i $\mathrm{OS}_{2} \Theta<\Theta_{\mathrm{r}}$. Na koti 
322 , koja je od kote 369 udaljena $12 \mathrm{~km}$, rastojanje između oblaka smetnji (baza $B$ ) jeste $B=\operatorname{tg} \Theta_{r} \cdot R=\operatorname{tg} 0,85^{\circ} \cdot 12000=178 \mathrm{~m}$. Izabrano je rastojanje od $100 \mathrm{~m}$, tj. $\mathrm{B}=100 \mathrm{~m}$. Merenja, kojih je bilo 20, vršena su u tri različite varijante, $\mathrm{i}$ to: $\mathrm{OS}_{1}=\mathrm{OS}_{2}$; $\mathrm{OS}_{1}>\mathrm{OS}_{2}$ i $\mathrm{OS}_{1}<\mathrm{OS}_{2}$. Vrednost uglovne greške uzeta je tek nakon 8 do $10 \mathrm{~s}$ u stabilnom praćenju.

Varijanta 1: $\mathrm{OS}_{1}=\mathrm{OS}_{2}(\mathrm{OS} \rightarrow$ Sl. 3; $\mathrm{OS}_{2} \rightarrow$ Sl. 3)

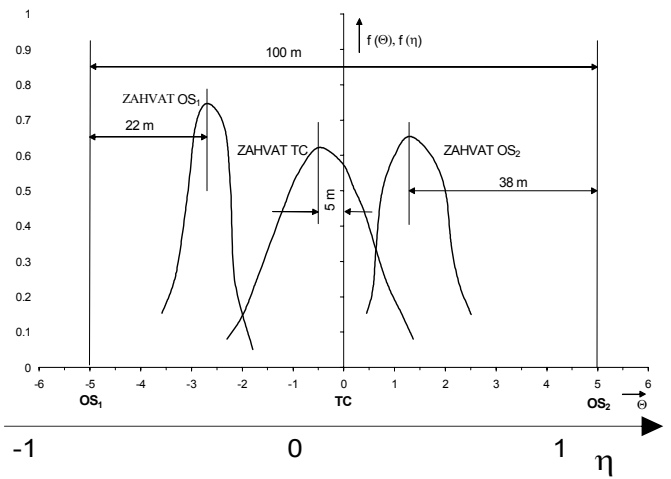

Sl. 7 - Eksperimentalne funkcije gustine verovatnoće pri $\mathrm{OS}_{1}=\mathrm{OS}_{2}$

Varijanta 2: $\mathrm{OS}_{1}>O S_{2}\left(O S_{1} \rightarrow\right.$ Sl. 3; $\mathrm{OS}_{2} \rightarrow \mathrm{Sl}$. 2)

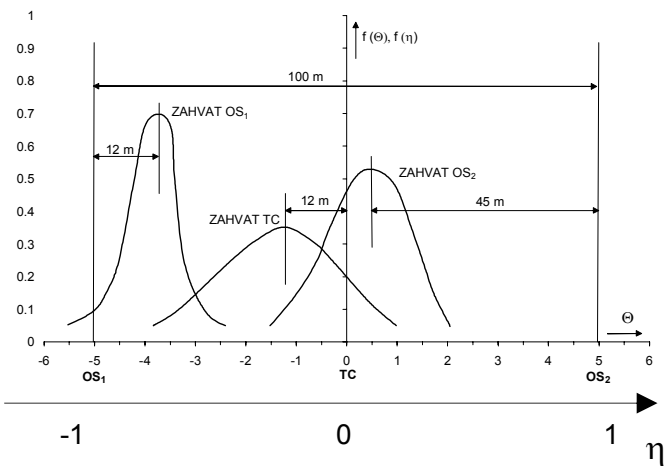

Sl. 8 - Eksperimentalne funkcije gustine verovatnoće pri $\mathrm{OS}_{1}>\mathrm{OS}_{2}$
Varijanta 3: $\mathrm{OS}_{1}<O S_{2}\left(O S_{1} \rightarrow\right.$ Sl. 2; $\mathrm{OS}_{2} \rightarrow$ Sl. 3)

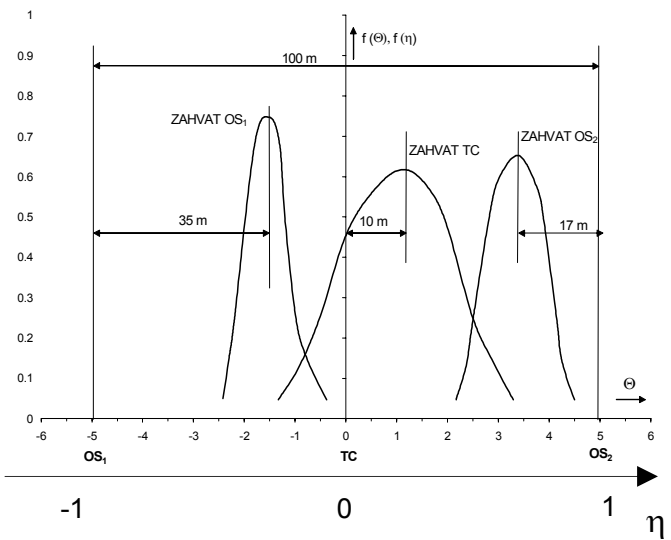

Sl. 9 - Eksperimentalne funkcije gustine verovatnoće pri $\mathrm{OS}_{1}<\mathrm{OS}_{2}$

Eksperiment 1 pokazao je značaj konfiguracije oblaka smetnji sa stanovišta ometanja monoimpulsnog radara. Svejedno je da li je radar na zemlji, a oblaci smetnji u vazdušnom prostoru, ili su oblaci neposredno na zemlji, a ometa se RGS protivradarske rakete. Takvo proširenje analize moguće je na osnovu oblaka smetnji [1]. Pitanje je samo u koju grupu treba svrstati realizovane oblake smetnji na zemlji. Odgovor na to pitanje je veoma diskutabilan. Možda je najispravnije reći da su oblaci smetnji u scenariju sa slike 4 formirani gotovo od svih modela, jer se ovde, pored signala uglovnih reflektora, superponiraju i signali stalnih odraza. Nameće se potreba da se posebno ispita struktura samih oblaka smetnji, što nije bio cilj ovih eksperimenata. Ovde se ograničilo samo na pojavni oblik, tj. na sistemski pristup uticaja oblaka smetnji.

Slučaj „Zahvat TC“ odgovara situaciji kada se ni na koji način ne može uticati na položaj optičke ose antene, odno- 
sno ESP u trenutku zahvata, tako da je zahvat izvršen po težišnom centru (TC) reflektovanog signala.

Slučaj ,Zahvat $\mathrm{OS}_{1}$ “ odgovara situaciji kada je $\mathrm{OS}_{1}$ na mestu letelice - cilja, a $\mathrm{OS}_{2}$ predstavlja oblak smetnji koji je formirala letelica - cilj $\mathrm{OS}_{1}$.

Slučaj ,Zahvat $\mathrm{OS}_{2}$ “ odgovara obrnutoj situaciji, kada je $\mathrm{OS}_{2}$ objekat zahvata, odnosno letelica - cilj, a $\mathrm{OS}_{1}$ predstavlja oblak smetnji.

Funkcija gustine verovatnoće u slučaju zahvata $\mathrm{OS}_{1}$ (slika 7) pokazuje da je najverovatniji položaj ESP NR-a pomaknut $22 \mathrm{~m}$ od cilja. To je uglovna greška, jer $10 \mathrm{~m}$ baze odgovara jednom podeoku na skali azimuta servosistema NR-a, u konkretnim geometrijskim odnosima radara i oblaka smetnji. Širina dijagrama zračenja predajnika osvetljenja, koji se usmerava pomoću NR je $1^{\circ}$, tj. identičan širini dijagrama zračenja NR-a. To znači da luk dijagrama zračenja predajnika osvetljavanja na $12 \mathrm{~km}$ iznosi $210 \mathrm{~m}$. Do prekida osvetljenja cilja dolazi tek kada uglovna greška u praćenju cilja prelazi maksimalno dozvoljenu grešku $\Theta_{\max }=210 / 2=105 \mathrm{~m}$. Greška od $22 \mathrm{~m}$ je manja od $\Theta_{\max }$, tako da nema štete po proces navođenja rakete na cilj.

Kada se radi o ometanju vođenja rakete na cilj, situacija je znatno drugačija. Maksimalno dozvoljena greška $\Theta_{\max } u$ navođenju rakete na cilj jednaka je poluprečniku zone uništenja bojne glave rakete, koji je u ovom slučaju, uz verovatnoću uništenja cilja 0,8 , jednak $20 \mathrm{~m}$. Prema tome, $22 \mathrm{~m}>\Theta_{\max }=20 \mathrm{~m}$ tako da je ometanje uspešno, odnosno promašaj rakete je verovatan.

Ista je situacija sa protivradarskom raketom. U ovom slučaju PRR zahvata radar - cilj aproksimiran oblakom smetnji $\mathrm{OS}_{1}$ i leti prema njemu. Zbog uticaja oblaka smetnji $\mathrm{OS}_{2}$, ESP radarske glave PRR pomaknut je $22 \mathrm{~m}$ u smeru $\mathrm{OS}_{2}$. Pitanje je samo koliki je poluprečnik zone uništenja bojne glave PRR. Bez obzira na razne podatke, agresija NATO na Jugoslaviju pokazala je da promašaj PRR više od $10 \mathrm{~m}$ ne dovodi do velikog oštećenja radara. Neka je onda $\Theta_{\max }=10 \mathrm{~m}$. Promašajem PRR od $22 \mathrm{~m}$ obezbeđena je potpuna zaštita radara.

Bitno drugačija situacija je u slučaju da se $\mathrm{OS}_{2}$ proglasi ciljem. Môda funkcije gustine verovatnoće pomaknuta je $38 \mathrm{~m}$ od $\mathrm{OS}_{2}$. Nišanski radar NR u tim uslovima obezbeđuje osvetljenje cilja, jer je $38 \mathrm{~m}<\Theta_{\max }=105 \mathrm{~m}$. PA raketa promašuje cilj jer je $38 \mathrm{~m}>\Theta_{\max }=20 \mathrm{~m}$. Protivradarska raketa takođe promašuje cilj, jer je $38 \mathrm{~m}>\Theta_{\max }=10 \mathrm{~m}$.

Zahvat TC u obavljenim eksperimentima nema veću praktičnu vrednost. Ostvaren je zbog dokazivanja teorije zahvata i praćenja složenog cilja. Složeni cilj, u ovom slučaju, formiran je od oblaka smetnji $\mathrm{OS}_{1}, \mathrm{OS}_{2}$ i neizbežnih stalnih odraza na mestu postavljanja $\mathrm{OS}_{1} \mathrm{i} \mathrm{OS}_{2}$.

Varijante 2 i 3 eksperimenta 1 potvrđuju važnost izbora konfiguracije oblaka smetnji. Čak i vizuelna promena sastava oblaka smetnji utiče na vrednosti uglovnih grešaka, što je dobro sa stanovišta praktične primene oblaka.

U varijanti 2 (slika 8) stiče se utisak kao da je kompletna slika 7 pomaknuta prema $\mathrm{OS}_{1}, \mathrm{tj} . \mathrm{OS}_{1}$, vuče“ funkciju gustine verovatnoće prema sebi, jer je $\mathrm{OS}_{1}>\mathrm{OS}_{2}$.

U varijanti 3 je obrnuto. Oblak smetnji $\mathrm{OS}_{2}$ „vuče“ gustine verovatnoće 
prema sebi, jer je $\mathrm{OS}_{2}>\mathrm{OS}_{1}$. Tako, na primer, zbog lošeg izbora konfiguracije $\mathrm{OS}_{2}$ u varijanti 2 cilj $\mathrm{OS}_{1}$ se ne može zaštititi od PA rakete, a što se tiče PRR na samoj je granici, jer je môda funkcije distribucije svega $12 \mathrm{~m}$ udaljena od $\mathrm{OS}_{1}$. Pri tome je možda važnije to što je $\mathrm{OS}_{1}$ „ispod“ krivulje funkcije gustine verovatnoće zahvata $\mathrm{OS}_{1}$. Verovatnoća pogotka radara protivradarskom raketom nije nula.

U varijanti 3 (slika 9) letelica - cilj $\mathrm{OS}_{1}$ je zaštićena od PA rakete, a radar cilj $\mathrm{OS}_{1}$ od PRR, jer je môda funkcije gustine verovatnoće na $35 \mathrm{~m}$ od $\mathrm{OS}_{1}$. Medutim, cilj $\mathrm{OS}_{2}$ u ovoj varijanti je gotovo $\mathrm{u}$ situaciji $\mathrm{OS}_{1}$ sa slike 8 . Udaljenost môde funkcije gustine verovatnoće od $\mathrm{OS}_{2}$ je svega $17 \mathrm{~m}$.

Eksperiment $1 \mathrm{u}$ svim varijantama pokazao je da $\mathrm{OS}_{2}$ manje ,vuče“ ESP antene NR-a (RGS PA rakete ili RGS PRR). Očigledno je da su se tu umešali stalni odrazi svojim uticajem, mada se vizuelno na terenu nisu uočavale određene nehomogenosti. Možda je odgovor u činjenici da je levo od $\mathrm{OS}_{1}$ (slika 4) bilo brdo sa repetitorom, koje je moglo formirati dodatnu svetlu tačku pored oblaka smetnji $\mathrm{OS}_{1}$. U prilog ovoj mogućnosti ide činjenica da je u pripremnom periodu eksperimenta, kada su se vršili probni zahvati stalnih odraza radi ispitivanja fona, repetitorska antena imala izvanredan odraz. Veoma lako se mogla zahvatiti i držati u režimu automatskog praćenja. Izbor radarskog položaja i položaja oblaka smetnji je, prema tome, veoma važan. Verovatno da $100 \mathrm{~m}$ pomaka u određenom smeru može biti odlučujuće. Rešenje bi se moglo naći u tome da svaka ra- ketna jedinica izvrši detaljno ,sondiranje“ mogućih radarskih položaja na predviđenom terenu, po metodici kojom su se i ovi eksperimenti vršili. Pokazalo se da su za to u potpunosti dovoljne sopstvene snage raketnog puka PVO. Određena deformacija dijagrama zračenja antene NRa takođe ide u prilog potrebi snimanja položaja. U [5] je pokazano kako se dijagram zračenja NR deformiše po mesnom uglu. To se isto događa i po azimutu, mada znatno manje, što ipak treba proveriti. Sa tako snimljenim dijagramom zračenja ulazi se u proračun rezolucionog ugla $\Theta_{r}$ sa znatno većom pouzdanošću, tako da se rezultati mogu predvideti sa većom tačnošću.

Eksperimentom 2, koji je vršen pri $\Theta<\Theta_{r}$ dokazana je teorijska tvrdnja da se podsvetljavanjem oblaka smetnji može dodatno uticati na položaj ESP NR-a.

Nišanski radar $\mathrm{NR}_{\mathrm{OM}}$, koji radi samo na predaji, usmeren je na $\mathrm{OS}_{2}$. Oblak smetnji $\mathrm{OS}_{2}$ izabran je za osvetljavanje zbog toga što se u eksperimentu 1 pokazao slabijim izvorom signala. Da bi se izbeglo osvetljavanje $\mathrm{OS}_{1}$, antena $\mathrm{NR}_{\mathrm{OM}}$ je pomaknuta udesno, toliko da je $\mathrm{OS}_{2}$ osvetljavala levim bokom glavne lepeze dijagrama zračenja antene $\mathrm{NR}_{\mathrm{OM}}$.

Osvetljeni oblak smetnji $\mathrm{OS}_{2}$ znatno više privlači ESP nišanskog radara NR. Môda funkcije gustine verovatnoće zahvata $\mathrm{OS}_{1} \mathrm{u} 1$. varijanti je sa $22 \mathrm{~m}$ iz eksperimenta 1 pomaknuta na $45 \mathrm{~m}$ od $\mathrm{OS}_{1}$. To je duplo veća vrednost. U varijanti 2 pokazano je da funkcija gustine verovatnoće još uvek ostaje dovoljno daleko od $\mathrm{OS}_{1}$, čak i ako se $\mathrm{OS}_{1}$ znatno poveća u odnosu na $\mathrm{OS}_{2}$. Ako se u kombinacijama oblaka smetnji desi da je $\mathrm{OS}_{2}$, pored toga 
što je osvetljen, veći od $\mathrm{OS}_{1}$, onda je zaštita $\mathrm{OS}_{1}$ od PA rakete ili PRR znatno poboljšana. To ide u prilog primeni imitatora radarskog zračenja za zaštitu od PRR osvetljavanjem oblaka smetnji.

$\mathrm{U}$ toku daljih ispitivanja $\mathrm{u}$ eksperimentu 3 je izabran telesni ugao oblaka smetnji $\Theta$ jednak rezolucionom uglu $\Theta_{\mathrm{r}}$ tj. $\Theta=\Theta_{\mathrm{r}}$.

Cilj eksperimenta 3 bio je da se pokaže značaj poznavanja tačne vrednosti rezolucionog ugla $\Theta_{\mathrm{r}}$. Zbog toga su oblaci smetnji formirani na isti način kao $u$ eksperimentu 2, ali je njihovo rastojanje promenjeno u smeru iznalaženja rezolucionog ugla. Rezultati su pokazali da smo bili blizu tog ugla. Otežan zahvat, veoma kratko i nestabilno automatsko praćenje izabrane tačke, velika disperzija položaja pseudocentra odraza, osnovne su karakteristike merenja u ovom eksperimentu. Sređivanje rezultata je, ipak, pokazalo potpunu zakonomernost. Môde funkcije gustine verovatnoće su se mogle uočavati. To dokazuje da je u ovako formiranim oblacima smetnji teško odrediti rezolucioni ugao $\Theta_{\mathrm{r}}$, ali da on zaista postoji. Međutim, mi nismo bili u rezolucionom uglu, što se pokazalo kroz činjenicu da su se funkcije gustine verovatnoće ipak pomerale po osi $\Theta$ u zavisnosti od vrste oblaka smetnji. U ovakvim uslovima teško je govoriti o zaštiti npr. letelice - cilja $\mathrm{OS}_{1}$ ili radara - cilja $\mathrm{OS}_{1}$, itd.

Slučajnost zahvata svih tačaka je velika, mada sa veoma malim verovatnoćama. Ipak, uočava se da je poželjno „pojačanje“ oblaka smetnji $\mathrm{OS}_{2}$ čak i u ovakvoj situaciji. Môda funkcije gustine verovatnoće je, doduše pomaknuta za $68 \mathrm{~m} \mathrm{od} \mathrm{OS}_{1}$, ali levi krak funkcije skoro dodiruje ovaj oblak smetnji. Verovatnoća pogotka $\mathrm{OS}_{1}$ nije nula.

Eksperiment 4 vršen je po metodici

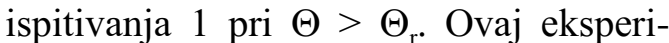
ment je pokazao da slučajan izbor konfiguracije oblaka smetnji pri $\Theta>\Theta_{\text {r nije }}$ pogodan za uspešnu zaštitu od NR ili PA rakete ili PRR. Ovde se još jednom pokazala inferiornost položaja oblaka smetnji $\mathrm{OS}_{2}$. Teško je reći da li je tome dodatno doprinela moguća pretpostavka da su se „mali“ uglovni reflektori u $\mathrm{OS}_{2}$,utopili““ $\mathrm{u}$ okolni teren ili je to normalno pri $\Theta>\Theta_{r}$. Naravno da razlog velikog pomeranja môda funkcija gustina verovatnoća ulevo može biti dovoljno jak izvor signala oblaka smetnji $\mathrm{OS}_{1}$. Pokazalo se da pri $\Theta>\Theta_{\mathrm{r}}$ ovako formiran oblak smetnji $\mathrm{OS}_{2}$ ne utiče na zahvat i praćenje $\mathrm{OS}_{1}$. Nikakva zaštita položaja $\mathrm{OS}_{1}$ nije ostvarena, što nije slučaj ako se položaj $\mathrm{OS}_{2}$ proglasi za cilj. Zaštita je kompletna. Očigledno da uslovi ove varijante pogoduju zahvatu težišnog centra parnog cilja $\mathrm{OS}_{1}$ $\mathrm{OS}_{2}$, koji je gotovo kompletno privukao i zahvat $\mathrm{OS}_{2}$. Iz navedenih razloga oblak smetnji $\mathrm{OS}_{2}$ je u daljim eksperimentima pojačan formiranjem konfiguracije prikazane na slici 3, dok je oblak smetnji $\mathrm{OS}_{1}$ ostao bez promene. Očekivani efekat je ostvaren, što je dobro, jer se time dokazuje da je procesom u praksi moguće upravljati.

Môda funkcije gustine verovatnoće zahvata $\mathrm{OS}_{1}$ pomerena je prema $\mathrm{OS}_{2}$ za čitavih $50 \mathrm{~m}$, što je ogromna promena u odnosu na prethodnu varijantu. $U$ takvim uslovima samo nišanski radar NR nesmetano vrši svoju funkciju, jer je $50 \mathrm{~m}<\Theta_{\max }=105 \mathrm{~m}$. Raketa i protivradarska raketa imaju velike promašaje. In- 
teresantan je slučaj zahvata $\mathrm{OS}_{2}$. Dobijena je dvomodna funkcija, gustine verovatnoće. Obe su dovoljno daleko od $\mathrm{OS}_{2}$ $\left(80 \mathrm{~m}\right.$ i $48 \mathrm{~m}$ ) tako da je zaštita $\mathrm{OS}_{2}$ od PA rakete i PRR takođe ostvarena. Nišanski radar NR pri tome omogućava osvetljavanje cilja, jer je $80 \mathrm{~m}<\Theta_{\max }=105 \mathrm{~m}$.

Oblak smetnji $\mathrm{OS}_{2}$ je u nepovoljnijoj situaciji, ako je pre poletanja PA rakete ili PRR došlo do prezahvata sa $\mathrm{OS}_{2}$ na težišni centar TC. Oblak smetnji $\mathrm{OS}_{2}$ je u tom slučaju ,ispod“ krivulje ,zahvat TS“, mada je môda čak $35 \mathrm{~m}$ daleko od $\mathrm{OS}_{2}$.

Narednim eksperimentom je imitiran rad protivradarske rakete: oblaci smetnji $\mathrm{OS}_{1} \mathrm{i} \mathrm{OS}_{2}$ se osvetljavaju predajnikom $\mathrm{NR}_{\mathrm{OM}}$, a nišanski radar NR radi u režimu prijema. Ostali uslovi identični su uslovima u eksperimentu 1.

Eksperiment je prvenstveno dokazao validnost pretpostavke da se i prethodni eksperimenti mogu koristiti za analizu ponašanja protivradarskih raketa. Rezultati su očekivani pošto su nišanski radari $\mathrm{NR}_{\mathrm{OM}}$ i NR identični. U eksperimentu je praktično nišanski radar NR „pozajmio“ predajnik od nišanskog radara - ometača $\mathrm{NR}_{\mathrm{OM}}$. Osim toga, ako se posmatra sa mesta oblaka smetnji, NR i $\mathrm{NR}_{\mathrm{OM}}$ su faktički u istoj tački.

\section{Zaključak}

Osnovni doprinos eksperimenata koji su opisani u ovom radu je u tome što je teorija oblaka smetnji prvi put dokazana u realnim, terenskim uslovima, $u$ organizaciji u kojoj je angažovan kompletan raketni puk PVO.
Zaključak koji proizilazi iz svih eksperimenata jeste da ometanje nišanskog radara, koji se nalazi u osnovi svih režima gađanja ciljeva u vazdušnom prostoru, nijednog trenutka nije poremetilo osvetljenje cilja predajnikom osvetljenja, što je od suštinskog značaja za vođenje PA rakete na cilj. Zbog toga se, pre svega, može očekivati primena protivradarskih raketa za fizičko uništavanje radarskih sredstava raketnog sistema. Ovim eksperimentima dokazana je pretpostavka da se znalačkom primenom oblaka smetnji protivradarska raketa može skrenuti sa svoje putanje, čime se povećava verovatnoća preživljavanja radara. Posebno, istom metodologijom, dokazano je da se i PA raketa isto tako uspešno može skrenuti sa svoje putanje primenom oblaka smetnji u vazdušnom prostoru.

Dalji rad u ovoj oblasti trebalo bi da bude nastavak istraživanja na osnovu pune konfiguracije eksperimenta, uključivanjem helikoptera u eksperiment. Time bi se mogli proveriti i fazni režimi rada radara u uslovima primene oblaka smetnji.

Literatura:

[1] Gacović, Č.: Oblak smetnji kao reprezent ometanja monoimpulsnih radara iz više tačaka u prostoru, Naučnotehnički pregled, Vol. 1, L 11, br. 1, 2002.

[2] Gacović, Č.: Nišanski radari PVO u protivelektronskoj borbi, Kumulativna naučno-tehnička informacija, VTI Beograd, 1991.

[3] Leroy, B. V. B.: Applied ECM, Electronic Warfare, March/April 1977, Vol. 1.

[4] Gacović, Č.: Raketni sistemi PVO u protivelektronskoj borbi, Vojnoizdavački zavod, Beograd, 1989.

[5] Gacović Č.: Praćenje niskoletećih ciljeva monoimpulsnim nišanskim radarom, Vojnoizdavački zavod, Beograd, 1999.

[6] Леонов, А. И.; Фомичев, К. И.: Моноимпулсная радиолокация, Радио и связь, Москва, 1984.

[7] Судаков, О. А.: Коррекция диаграммы направленности антенны методом фильтрации, Радиотехника и электроника, 4/1989. 